\title{
INVESTIGATING LITERARY TERMINOLOGIES TO ACCOMPLISH LITERARY RESEARCH AND ENJOYMENT: A CORPUS STUDY
}

\author{
Agista Nidya Wardani ${ }^{1)}$, Adityo ${ }^{2)}$ \\ 1) University Muhammadiyah Malang, Indonesia \\ E-mail: agista@umm.ac.id \\ 2) University of Muhammadiyah Malang, Indonesia \\ E-mail: adityo@umm.ac.id
}

\begin{abstract}
In relation to producing, enjoying, and especially criticizing literature, some literary terminologies are used frequently. Thus, corpus in the field of Literature is urgently needed to compile. This study aims to compile literary terminologies found in Literature and Language Teaching by Gillian Lazar and Literary Movements for Students by Ira Mark Milne books. In addition, it also tries to find the frequency, meaning (in context), and examples of the use of the terminologies. The method used in this research was document analysis, the data of which was obtained from predetermined documents, such as books of general literature, and books of theory and literary criticism. While the stages carried out were data collection, data selection, and presentation. From the books studied, it is found that the terminologies that appear could be categorized into terminologies related to (1) authors, (2) readers of literary works, (3) literary work itself, and (4) literary theory and criticism. Additionally, there is an interesting fact from the data found that the books have different frequencies of literary terminologies. The terminologies that appeared in Literary Movements for Students are more frequent.
\end{abstract}

Keywords: corpus; glossary; literary terminologies; literature

\section{INTRODUCTION}

Literary works, both fiction and non-fiction, always accompany human routines, such as television series shows, advertisements, and even essay assignments. Humans have to produce and enjoy literary works by themselves. Aside from being an author and readers, humans are also literary critics. In relation to producing, enjoying, and especially criticizing literature, some literary terminologies are used frequently. According to Bara (2012), studying terminologies is very important as each discourse needs different terminologies. Thereto, terminologies become a prescriptive discipline, as opposed to the descriptive one, and slowly become parts of general linguistics (Siqueira, M. et al., 2009). In literature, some terminologies of other disciplines are borrowed. In other words, literature is an interdisciplinary field. According to Zepetnek (1998), the interdisciplinary nature of literature makes literature can be examined by using concepts in psychology, history, or other fields of art. In addition, the principles and methods of these other fields can also be applied to the field of literature.

A literary researcher requires some literary terminologies, while there are few corpora available in the field of literature. Meanwhile, online, it is found a dictionary in the field of literature in the form of a website, the website address of which is kamuslengkap.com. In addition, there are electronic and printed dictionaries that contain literary terminologies in the title Dictionary of Literary Terms compiled by Abdul Rozak Zaidan, Anita K. Rustapa, and Hanrah. This dictionary is published by Balai Pustaka. Further, the Shakespearean dictionary has been made. They are Arden Shakespeare Dictionary and Shakespeare's Plants and Gardens (Karpova, 2018). Regarding these corpora, the number of corpora on literary terminologies is still very minimal. From the minimum number of dictionaries, it can be assumed that the tools to compile dictionaries are also minimal in number, including the literary corpus.

One of previous studies found is written by CuadradoEsclapez, et al. (2016), which tries to make a corpus of metaphors and metonimies found in some books in different fields, like engineering architecture, physical activity, and sports sciences. Additionally, Malekzadeh (2020) tries to find out the rhetorical structure used in translation and English literature abstracts. Other than that, in Oktavianti (2019), a corpus is made to find out modals used in Corpus of Contemporary American English and other academic 
texts. It focuses on discussing the frequency of modals and the kinds of modals.

This study aims to compile literary terminologies found in Literature and Language Teaching by Gillian Lazar and Literary Movements for Students by Ira Mark Milne books. In addition, it also tries to find the frequency, meaning (in context), and examples of the use of the terminologies. The terminologies compiled are not too broad, like hybrid dictionaries, and not too specific, like Shakespearean dictionaries. Additionally, glossary, one form of the corpora, has some advantages, one of them is to increase students' vocabulary mastery (Sari, 2016). Thus, in the hope of increasing the students' vocabulary or helping students understand the literary terminologies when doing a research on literature, the glossary is made. Besides, a corpus of certain terminologies or words is functional to research, like literary or linguistics research. A research by Andor (2016) does a corpus-based investigation of the word "unicorn" to strengthen the interpretation of this word in Iris Murdoch's novel, The Unicorn.

\section{A. Literature}

Literature is the imagination of the author. Because literature is the author's imagination, literature can have an unlimited world because imagination is also unlimited. Vygotsky (1930/2004) says that the way imagination operates is important to individual as it involves individual's experiences supplied by reality. Further, this experience is not only formed by personal feelings but also individual's time and environment.

\section{B. Literary Theory and Criticism}

Literary theory is a theory used to examine or commonly referred to as literary criticism. In literary research, there are four approaches used, namely mimetic approach, pragmatic approach, expressive approach, and objective approach (Abrams, 1953). A mimetic approach is an approach that focuses on the relationship between literature and the world outside it. This is because, based on the mimetic approach, literary work is the world outside the literary work itself.

Then, what is meant by a pragmatic approach is an approach that focuses on the relationship between literary works and the reader. In the pragmatic approach, it is believed that literary works are deliberately made to give effect to the reader.

While, an expressive approach is an approach that focuses on the relationship of literary works and their authors. In an expressive approach, it is believed that literary works are the thoughts of their authors. Lastly, an objective approach is an approach that focuses on the relationship of literary works with the things presented in them. This objective approach believes that literary work is for the literary work itself. Literary work has nothing to do with things outside it, such as the author, the background, and other external matters (Abrams, 1953).

\section{Literary Work and Its Author}

The creation of a literary work cannot be separated from its author. Therefore, one of the approaches to literary research is an expressive approach, which is an approach that focuses on the relationship of literary works with their authors (Abrams, 1953). In addition, it is also believed that literary works are the author's imagination.

On the other hand, there is a debate that the author is dead or better known as 'The Death of Author.' In this perspective, the author is no longer a reference when someone examines literature. The author's imagination or thought is rejected. Literary works exist only because of the background of the literary work itself, which is presented to the reader. Literary works exist as if there is no purpose (Compagno, 2012).

The purpose of the author, however, cannot be rejected just like that. The creator remains a reference when researchers want to know the meaning of a literary work. The author must be a reference because if he/she is not, the researcher will only look for meaning by just guessing and falling on the discovery of meaning that is not in accordance with the origin (Compagno, 2012).

\section{Literary Work and Its Reader}

According to Hans Robert Jauss (1982 there is a dialectic between the literary work and its reader. According to him, literary works are read through the creativity process possessed by the readers. For this reason, readers have an important place in literature. Literary work is believed to be a combination of text and reader subjectivity. It is not only the text or not only the reader's subjectivity.

Added by Wolfgang Iser (1974), the text could only exist if there is awareness. The awareness appears by readers' subjectivity or thoughts. In relation to the subjectivity of readers of literature, according to Hans-Georg Gadamer (in Hasanah, 2017), the meaning of literary works in the past is very dependent on the present. This is because the readers' thoughts of the present are closely related to the things that happen in the present, which are certainly different from the things that happened in the past.

\section{E. Corpus}

A corpus is a collection of words that are naturally arranged or not made up. It is arranged by following a certain extralinguistic system (Budiwiyanto, 2014).

The history of corpus development is quite long. Data collection for the corpus was carried out in the late 1950s by Randolph Quirk, and in the mid-1980s, computerized data was carried out. This program is called International Corpus of English (ICE). In the 1960s, Nelson Francis and Henry Kucera developed Brown Corpus. Brown Corpus has very few errors because it has been through proofread several times. Next, in 1963, English Lexical Studies was compiled. This corpus specifically discusses lexical research. In the mid-1970s, the first corpus used for dictionaries was made (Budiwiyanto, 2014). 
There are various types of the corpora, namely general corpus, historical corpus, regional corpus, learning corpus, multilingual corpus, and oral corpus. A general corpus is a corpus that describes a whole language. A historical corpus is a corpus that contains the origin of a language. A regional corpus is a corpus that describes a language that is used in a particular region. A learning corpus is a corpus that describes a language used by learners. A multilingual corpus is a corpus that explains a certain thing using more than one language. An oral corpus is a corpus that explains spoken language (Budiwiyanto, 2014).

Hartmann (2005) says that we enter a trend in which a dictionary tends to be more specific, not a hybrid, like a dictionary of terminologies in a certain field, bilingual dictionary (thematic dictionary), technical glossary, and many others. A specific dictionary responds some puzzlements that are not answered by the hybrid dictionary. Additionally, dictionaries or glossaries for learners become high in demand as its function to provide information (Karpova, 2019).

To conduct a linguistic corpus study, a researcher should consider some items to sort:

"The key strength of corpus linguistics is its ability to find, sort, and count items as a basis for linguistic description...Specialists, report that monolingual corpus-based lexicography is well-suited to addressing six research questions: word meanings, word frequencies, association and connotation patterns, collocation, word sense, and use, and use and distribution of synonyms" (Munday in Zemke, 2017: p. 227)

\section{MethodOLOGY}

This research used a document analysis method. It means that the researcher collected documents, such as general literature and literary theory and criticism books. This step is to take the terminologies contained therein as data.

The material objects of this research were a book of literature in English language teaching, namely Literature and Language Teaching by Gillian Lazar, and a book of literary theory and criticism, namely Literary Movements for Students by Ira Mark Milne. The formal objects of this research were terminologies related to literature presented in the books.

The stages of data collection were: (1)listing the books with titles, authors, and publishers which would be used as material objects of the research; (2) collecting books that had been listed; (3) reading the books that had been obtained to find the literary terminologies; (4) marking on the terminologies that had been found; and (5) tabulating the terminologies that had been marked

Collecting the data, the next steps to analyze the data were: (1) counting the frequency of the terminologies that appeared in the books; (2) looking for meanings and examples of the use of terminologies in dictionaries and books that became the material object; (3) arranging the terminologies based on the order of the initial alphabet letters; and (4) presenting the terminologies, their meanings, and examples of their use in a mini corpus.

\section{RESULTS AND DISCUSSION}

\section{F. LITERARY TERMinologies IN ENGLISH AND BAHASA INDONESIA}

The terminologies found in Literature and Language Teaching by Gillian Lazar and Literary Movements for Students by Ira Mark Milne are as follows:

TABLE I

LITERARY TERMINOLOGIES IN ENGLISH

\begin{tabular}{|c|c|c|c|c|}
\hline \multirow{2}{*}{$\begin{array}{l}\text { Ter } \\
\text { min } \\
\text { olog } \\
\text { ies }\end{array}$} & \multicolumn{4}{|c|}{$\begin{array}{c}\text { Source: Lazar, G. (2002). Literature and Language Teaching. } \\
\text { Cambridge: Cambridge University Press. }\end{array}$} \\
\hline & $\begin{array}{l}\text { Part of } \\
\text { Speech }\end{array}$ & Frequency & $\begin{array}{l}\text { Meaning } \\
\text { (in context) }\end{array}$ & Example of Usage \\
\hline $\begin{array}{l}\text { Allit } \\
\text { erati } \\
\text { on }\end{array}$ & $\mathrm{N}$ & 8 & $\begin{array}{l}\text { Repetition of } \\
\text { consonant } \\
\text { sound at the } \\
\text { beginning of } \\
\text { words } \\
\text { positioned } \\
\text { near to each } \\
\text { other }\end{array}$ & $\begin{array}{l}\text { assonance and } \\
\text { alliteration can be } \\
\text { found in children's } \\
\text { rhymes and } \\
\text { advertising jingles. }\end{array}$ \\
\hline $\begin{array}{l}\text { Asso } \\
\text { nanc } \\
\text { e }\end{array}$ & $\mathrm{N}$ & 9 & $\begin{array}{l}\text { Repetition of } \\
\text { a vowel } \\
\text { sound in the } \\
\text { middle or in } \\
\text { the last } \\
\text { words } \\
\text { positioned } \\
\text { near to each } \\
\text { other }\end{array}$ & $\begin{array}{l}\text { assonance and } \\
\text { alliteration can be } \\
\text { found in children's } \\
\text { rhymes and } \\
\text { advertising jingles. }\end{array}$ \\
\hline $\begin{array}{l}\text { Chro } \\
\text { nolo } \\
\text { gical } \\
\text { sequ } \\
\text { ence }\end{array}$ & Adj & 2 & $\begin{array}{l}\text { Order of } \\
\text { events based } \\
\text { on the time }\end{array}$ & $\begin{array}{l}\text { It is common in both } \\
\text { short stories and } \\
\text { novels for the } \\
\text { chronological } \\
\text { sequence of events to } \\
\text { be disrupted, for } \\
\text { example, through the } \\
\text { use of flashback. }\end{array}$ \\
\hline $\begin{array}{l}\text { Criti } \\
\text { cal }\end{array}$ & Adj & 24 & $\begin{array}{l}\text { Of or relating } \\
\text { to analyzing, } \\
\text { appreciating, } \\
\text { or evaluating } \\
\text { literary works }\end{array}$ & $\begin{array}{l}\text { Literature itself has } \\
\text { been greatly enriched } \\
\text { by recent } \\
\text { developments in } \\
\text { the field of critical } \\
\text { theory. }\end{array}$ \\
\hline $\begin{array}{l}\text { Criti } \\
\text { cism }\end{array}$ & $\mathrm{N}$ & 9 & $\begin{array}{l}\text { The act of } \\
\text { analyzing, } \\
\text { appreciating, } \\
\text { and evaluating } \\
\text { literary works }\end{array}$ & $\begin{array}{l}\text { In the teaching of } \\
\text { literature, traditional } \\
\text { practical criticism has } \\
\text { relied on } \\
\text { the intuitions of the } \\
\text { reader to form critical } \\
\text { judgements. }\end{array}$ \\
\hline
\end{tabular}




\begin{tabular}{|c|c|c|c|c|}
\hline \multirow[t]{2}{*}{$\begin{array}{l}\text { Termi } \\
\text { nologies }\end{array}$} & \multicolumn{4}{|c|}{$\begin{array}{c}\text { Source: Milne, I.M. (2009). Literary Movements for Students. } \\
\text { Detroit: Gale Cengage Learning. }\end{array}$} \\
\hline & $\begin{array}{l}\text { Part of } \\
\text { Speech }\end{array}$ & $\begin{array}{l}\text { Fre } \\
\text { que } \\
\text { ncy }\end{array}$ & $\begin{array}{l}\text { Meaning } \\
\text { (in } \\
\text { Context) }\end{array}$ & Example of Usage \\
\hline Absurdist & N/adj & $\begin{array}{l}4 \\
8\end{array}$ & $\begin{array}{l}\text { One believing } \\
\text { that human's } \\
\text { life will } \\
\text { always be in } \\
\text { vain }\end{array}$ & $\begin{array}{l}\text { Like the } \\
\text { surrealists, the } \\
\text { absurdists valued } \\
\text { dreamlike } \\
\text { images over logical, } \\
\text { rational thought. Unlike } \\
\text { the surrealists, however, } \\
\text { who attempted to create } \\
\text { a positive and } \\
\text { constructive reaction to } \\
\text { the horror, } \\
\text { the absurdists believed } \\
\text { that human life was } \\
\text { meaningless } \\
\text { and that humans were } \\
\text { helpless creatures, } \\
\text { having fallen into a } \\
\text { state of absurdity. }\end{array}$ \\
\hline Canon & $\mathrm{N}$ & $\begin{array}{l}3 \\
8\end{array}$ & $\begin{array}{l}\text { Literary } \\
\text { works } \\
\text { considered to } \\
\text { have high } \\
\text { values }\end{array}$ & $\begin{array}{l}\text { Scholars } \\
\text { overwhelmingly } \\
\text { acknowledge the debt } \\
\text { the Western canon owes } \\
\text { to the ancient Greeks } \\
\text { and Romans, for their } \\
\text { contributions not only } \\
\text { to } \\
\text { Western literature but to } \\
\text { Western culture as a } \\
\text { whole. }\end{array}$ \\
\hline Canonical & Adj & 2 & $\begin{array}{l}\text { Of, relating } \\
\text { to, literary } \\
\text { works } \\
\text { considered to } \\
\text { have a high } \\
\text { value }\end{array}$ & $\begin{array}{l}\text { In the } 10 \text { th and } \\
11 \text { th centuries several } \\
\text { famous canonical } \\
\text { abbeys } \\
\text { were founded in } \\
\text { Saxony, which } \\
\text { developed a tradition } \\
\text { of female scholarship, } \\
\text { resulting in literary } \\
\text { figures like Hrosvitha. }\end{array}$ \\
\hline $\begin{array}{l}\text { Classicis } \\
\mathrm{m}\end{array}$ & $\mathrm{N}$ & $\begin{array}{l}2 \\
2 \\
3\end{array}$ & $\begin{array}{l}\text { Theory } \\
\text { focusing on } \\
\text { the } \\
\text { appreciation } \\
\text { of classical } \\
\text { period and } \\
\text { classical } \\
\text { antiquity of } \\
\text { Western } \\
\text { civilization }\end{array}$ & $\begin{array}{l}\text { Classicism both as an } \\
\text { art style and as the first } \\
\text { theory of art was } \\
\text { defined by the ancient } \\
\text { Greeks, } \\
\text { emulated by the } \\
\text { Romans, and then } \\
\text { continued to } \\
\text { appear in various forms } \\
\text { across the } \\
\text { centuries. }\end{array}$ \\
\hline Classicist & N/adj & $\begin{array}{l}4 \\
0\end{array}$ & $\begin{array}{l}\text { One } \\
\text { appreciating } \\
\text { classical } \\
\text { period and } \\
\text { classical } \\
\text { antiquity of } \\
\text { Western } \\
\text { civilization }\end{array}$ & $\begin{array}{l}\text { The publication } \\
\text { of the Aeneid ensured } \\
\text { Vergil's fame as a poet } \\
\text { and } \\
\text { classicist. }\end{array}$ \\
\hline
\end{tabular}

TABLE 2

LITERARY TERMINOLOGIES IN BAHASA INDONESIA

\begin{tabular}{|c|c|c|c|c|}
\hline \multirow{2}{*}{$\begin{array}{l}\text { Daft } \\
\text { ar } \\
\text { Istila } \\
h\end{array}$} & \multicolumn{4}{|c|}{$\begin{array}{l}\text { Sumber: Lazar, G. (2002). Literature and Language Teaching. } \\
\text { United Kingdom: Cambridge University Press. }\end{array}$} \\
\hline & $\begin{array}{c}\text { Kelas } \\
\text { Kata }\end{array}$ & Frekuensi & $\begin{array}{c}\text { Makna } \\
\text { (dalam } \\
\text { konteks) }\end{array}$ & Contoh Penggunaan \\
\hline $\begin{array}{l}\text { Alite } \\
\text { rasi }\end{array}$ & Nomina & 8 & $\begin{array}{l}\text { Pengulangan } \\
\text { suara } \\
\text { konsonan } \\
\text { pada awal } \\
\text { kata yag } \\
\text { dimulai di } \\
\text { dekat satu } \\
\text { sama lain } \\
\end{array}$ & $\begin{array}{l}\text { asonansi dan } \\
\text { aliterasi dapat } \\
\text { ditemukan dalam } \\
\text { lagu anak-anak dan } \\
\text { lagu iklan. }\end{array}$ \\
\hline $\begin{array}{l}\text { Ason } \\
\text { ansi }\end{array}$ & Nomina & 9 & $\begin{array}{l}\text { Pengulangan } \\
\text { suara vokal di } \\
\text { bagian tengah } \\
\text { atau belakang } \\
\text { kata yang } \\
\text { diposisikan di } \\
\text { dekat satu } \\
\text { sama lain }\end{array}$ & $\begin{array}{l}\text { asonansi dan } \\
\text { aliterasi dapat } \\
\text { ditemukan dalam } \\
\text { sajak anak-anak dan } \\
\text { lagu iklan. }\end{array}$ \\
\hline $\begin{array}{l}\text { Kriti } \\
k\end{array}$ & $N$ & 9 & $\begin{array}{l}\text { Tindakan } \\
\text { menganalisis, } \\
\text { menilai, dan } \\
\text { mengevaluasi } \\
\text { karya sastra }\end{array}$ & $\begin{array}{l}\text { Dalam mengajarkan } \\
\text { sastra, kritik praktis- } \\
\text { tradisional banyak } \\
\text { mengandalkan } \\
\text { intuisi pembaca } \\
\text { untuk merangkai } \\
\text { pemikiran kritis. }\end{array}$ \\
\hline $\begin{array}{l}\text { Kriti } \\
\text { kus }\end{array}$ & $N$ & 4 & $\begin{array}{l}\text { Seseorang } \\
\text { yang terlibat } \\
\text { dalam } \\
\text { menganalisis, } \\
\text { menilai, dan } \\
\text { mengevaluasi } \\
\text { karya sastra. } \\
\end{array}$ & $\begin{array}{l}\text { Kritikus sastra, } \\
\text { di sisi lain, } \\
\text { berkenaan dengan } \\
\text { interpretasi dan } \\
\text { evaluasi terhadap } \\
\text { karya sastra. }\end{array}$ \\
\hline $\begin{array}{l}\text { Kriti } \\
S\end{array}$ & Adj & 24 & $\begin{array}{l}\text { Terkait atau } \\
\text { berhubungan } \\
\text { dengan proses } \\
\text { menganalisis, } \\
\text { menilai, dan } \\
\text { mengevaluasi } \\
\text { karya sastra }\end{array}$ & $\begin{array}{l}\text { Ranah sastra } \\
\text { semakin berkembang } \\
\text { dengan } \\
\text { perkembangan } \\
\text { terkini dalam } \\
\text { bidang teori kritis. }\end{array}$ \\
\hline $\begin{array}{l}\text { Urut } \\
\text { an } \\
\text { kron } \\
\text { ologi } \\
\text { s }\end{array}$ & $\begin{array}{l}\text { Adjektiv } \\
\text { a }\end{array}$ & 2 & $\begin{array}{l}\text { Urutan } \\
\text { peristiwa } \\
\text { secara } \\
\text { kronologis }\end{array}$ & $\begin{array}{l}\text { Urutan kronologis } \\
\text { peristiwa, dalam } \\
\text { cerita pendek dan } \\
\text { novel, biasanya } \\
\text { dapat dikacaukan, } \\
\text { sebagai contoh } \\
\text { melalui penggunaan } \\
\text { kilas balik. }\end{array}$ \\
\hline
\end{tabular}

\begin{tabular}{|c|c|c|c|c|}
\hline \multirow{2}{*}{$\begin{array}{l}\text { Daf } \\
\text { tar } \\
\text { Istil } \\
\text { ah }\end{array}$} & \multicolumn{4}{|c|}{$\begin{array}{c}\text { Sumber: Milne, I.M. (2009). Literary Movements for Students. } \\
\text { Detroit: Gale Cengage Learning. }\end{array}$} \\
\hline & Kelas Kata & Frekuensi & $\begin{array}{c}\text { Makna } \\
\text { (dalam } \\
\text { konteks) }\end{array}$ & Contoh Penggunaan \\
\hline $\begin{array}{l}\text { Abs } \\
\text { urdi } \\
s\end{array}$ & N/adj & 48 & $\begin{array}{l}\text { Seseorang } \\
\text { yang percaya } \\
\text { bahwa } \\
\text { kehidupan } \\
\text { manusia } \\
\text { selalu dalam } \\
\text { kegagalan }\end{array}$ & $\begin{array}{l}\text { Seperti halnya } \\
\text { surealis, absurdis lebih } \\
\text { menghargai } \\
\text { penggambaran } \\
\text { yang tidak masuk akal, } \\
\text { alih-alih pemikiran logis } \\
\text { yang rasional. Namun, } \\
\text { tidak seperti } \\
\text { surealis yang mencoba } \\
\text { menciptakan reaksi }\end{array}$ \\
\hline
\end{tabular}




\begin{tabular}{|c|c|c|c|c|}
\hline & & & & $\begin{array}{l}\text { positif dan konstruktif } \\
\text { terhadap horor, } \\
\text { absurdis meyakini } \\
\text { bahwa kehidupan } \\
\text { manusia tidak bermakan } \\
\text { dan bahwa manusia } \\
\text { adalah makhluk tanpa } \\
\text { harapan } \\
\text { yang telah jatuh dalam } \\
\text { jurang absurditas. }\end{array}$ \\
\hline $\begin{array}{l}\text { Kan } \\
\text { on }\end{array}$ & Nomina & 38 & $\begin{array}{l}\text { Karya sastra } \\
\text { adi luhung }\end{array}$ & $\begin{array}{l}\text { Cendekiawan begitu } \\
\text { meyakini besarnya } \\
\text { pengaruh Yunani } \\
\text { dan Romawi kuno } \\
\text { terhadap karya kanon } \\
\text { Barat, karena kontribusi } \\
\text { mereka tidak terbatas } \\
\text { pada karya sastra } \\
\text { Barat, namun pada } \\
\text { budaya Barat secara } \\
\text { utuh. }\end{array}$ \\
\hline $\begin{array}{l}\text { Kan } \\
\text { onis }\end{array}$ & Adjektiva & 2 & $\begin{array}{l}\text { Berkaitan } \\
\text { dengan karya } \\
\text { sastra adi } \\
\text { luhung }\end{array}$ & $\begin{array}{l}\text { Pada abad ke-10 dan } \\
\text { ke-11, beberapa biara } \\
\text { kanonis terkemuka } \\
\text { didirikan di Saxon yang } \\
\text { mengembangkan tradisi } \\
\text { cendekiawan wanita, } \\
\text { yang menjadi latar } \\
\text { lahirnya } \\
\text { tokoh sastra, seperti } \\
\text { Hrosvitha. }\end{array}$ \\
\hline $\begin{array}{l}\text { Kla } \\
\text { sisi } \\
\text { s }\end{array}$ & N/adj & 40 & $\begin{array}{l}\text { Seseorang } \\
\text { yang } \\
\text { mengapresias } \\
\text { i periode } \\
\text { klasik dan } \\
\text { peninggalan } \\
\text { sejarah } \\
\text { periode klasik } \\
\text { peradaban } \\
\text { Barat } \\
\end{array}$ & $\begin{array}{l}\text { Terbitnya } \\
\text { Aeneid mengukuhkan } \\
\text { nama besar Vergil } \\
\text { sebagai penyair dan } \\
\text { klasisis. }\end{array}$ \\
\hline $\begin{array}{l}\text { Kla } \\
\text { sisi } \\
\text { sme }\end{array}$ & Nomina & 223 & $\begin{array}{l}\text { Teori yang } \\
\text { berfokus pada } \\
\text { apresiasi } \\
\text { periode klasik } \\
\text { dan } \\
\text { peninggalan } \\
\text { sejarah } \\
\text { periode klasik } \\
\text { peradaban } \\
\text { Barat }\end{array}$ & $\begin{array}{l}\text { Klasisisme, sebagai } \\
\text { aliran seni dan teori } \\
\text { seni } \\
\text { pertama yang } \\
\text { dicetuskan oleh } \\
\text { masyarakat Yunani } \\
\text { kuno, } \\
\text { diadaptasi oleh Romawi, } \\
\text { dan kemudian terus } \\
\text { muncul dalam beragam } \\
\text { bentuk sepanjang abad. }\end{array}$ \\
\hline
\end{tabular}

From the data obtained, it is shown that the terminologies of literature that appeared in the books were related to authors, readers, literary work itself, and literary theory and criticism. Additionally, the frequency of appearance of literary terminologies found in Literature and Language Teaching by Gillian Lazar was not as much as that found in Literary Movements for Students by Ira Mark Milne. For example, the word "poetry" in Literature and Language Teaching appeared 150 times, while in Literary Movements for Students appeared 936 times. As another example, the word "modernism" in the Literature and Language Teaching only appeared one time, while in the Literary Movements for Students, there are 467 words.

In Literary Movements for Students book, several literary terminologies related to the authors were found, such as "playwright" with 140 words, "absurdist" with 48 words, and "classicist" with 40 words. These words refer directly to the author, or they mean the authors themselves. "Playwright" means one writing a play or drama, "absurdist" means one believing that human life will always be in vain, and "classicist" means one appreciating classical period and classical antiquity of Western civilization. This terminology is very useful for researchers in researching because one of the approaches used in research is an approach that focuses on the relationship of literary works with their authors, namely an expressive approach (Abrams, 1953). In addition, there were other terms related to the authors, which were 227 "humanists" and 235 "imagists." In this case, the terminologies do not refer directly to the author, or they do not mean as the author themselves, but they are adjectives attributed to the author. The word "humanist" means one regarding the human's value and dignity, and the word "imagist" means characteristic owned by a poet focusing on precision use of imagery and language.

In addition to the terminologies related to the author, the terminologies found in these two books are also related to the reader of literature. The terminologies were "readerresponse" with one word and "response" with 23 words contained in the book Literature and Language Teaching. "Reader-response" means the theory focuses on the reader experiencing the literary work and "response" means the reader acts to a literary work. The reader-related terminology is very useful for literary researchers because reader is one of the focuses in researching literary works. This is as related to what is expressed by Hans Robert Jauss (1982), which is in literary works there is a dialectic between the literary work itself and its reader.

In addition to the terminologies related to the authors and readers of literature, it was found the terminologies related to the literary work itself, such as "assonance" as many as 9 words, "point of view" as many as 7 words, and "fable" as many as 1 word in the book Literature and Language Teaching. "Assonance" means repetition of a vowel sound in the middle or in the last words positioned near to each other. "Point of view" means angle in which a narrator in a literary work describes the whole things, and "fable" means fiction telling about animals, plants, or inanimate objects acting like humans. While in Literary 
Movements for Students book, it was found terminologies related to literary works, which are "canon" with 38 words and "canonical" with 2 words. "Canon" means literary works considered to have high values, and "canonical" means of, relating to, literary works considered to have high values. These terminologies are useful for literary researchers because in literary research, literary works have a place in an objective approach. An objective approach is an approach that focuses on the relationship of literary works with the things presented inside the literary works themselves. This objective approach believes that literary work is for the literary work itself. Literary work has nothing to do with things outside it, such as the author, the background that gave rise to it, and other external matters (Abrams, 1953).

Then, the terminologies that appeared are related to the theory and literary criticism. In Literature and Language Teaching book, the literary theory and criticism-related terminologies found are "criticism" as many as 9 words, "structuralism" as much as 1 word, and "deconstructionism" as much as 1 word. "Criticism" means the act of analyzing, appreciating, and evaluating literary works. "Structuralism" means theory focusing on belief that language is a system of signs and that literary work is related to another literary work, and "deconstructionsim" means theory focusing on looking for any possible meaning as there is no single truth or absolute meaning. While in Literary Movements for Students book, it was found several words related to theory and criticism, including 223 words of "classicism", 96 words of "postcolonialism", and 207 words of "postmodernism". "Classicism" means theory focusing on the appreciation of the classical period and classical antiquity of Western civilization, "postcolonialism" means theory focusing on a state of revival after being colonized, and "postmodernism" means movement or theory focusing on the continuation of the modern age.

\section{CONCLUSION}

From this study, it could be said that the terminologies of literature that arise in Literature and Language Teaching by Gillian Lazar are related to the authors of literary works, readers of literary works, literary works themselves, and literary theories and criticism. Besides, the terminologies that appear in Literary Movements for Students by Ira Mark Milne are also related to the authors of literary works, readers of literary works, literary works themselves, and literary theories and criticism. Interestingly, it could be concluded that the literary terminologies appeared in the two books studied are different infrequency. Literary terminologies in Literary Movements for Students had more frequent occurrence.

\section{ACKNOWLEDGMENT}

The writers would like to send gratitude to Faculty Teacher Training and Education, University of Muhammadiyah Malang, for the block grant given.

\section{REFERENCES}

Abrams, M.H. (1953). The mirror and the lamp: Romantic theory and critical tradition. Oxford University Press.

Andor, József. (2016). Whence the unicorn? A framesemantic and corpus linguistic interpretation of the notion of unicorn hood in the characterology of Iris Murdoch's novel: The Unicorn. Corela: Cognition, représentation, language, https://journals.openedition.org/corela/4496

Bara, Mariana.(2012). Globalization - direct and indirect effects on terminologies. Hypercultura, 1(1), 1-13. http://litere.hyperion.ro/hypercultura/wpcontent/uploads/2017/04/Bara-Mariana_pdf-1.pdf

Budiwiyanto, Adi. (2014) Korpus dalam Penyusunan Kamus. Badan

Bahasa.

http://badanbahasa.kemdikbud.go.id/lamanbahasa/c ontent/korpus-dalam-penyusunan-kamus

Compagno, Dario. (2012). Theories of authorship and intention in the twentieth century: an overview. Journal of Early Modern Studies, 1(1), 37-53. http://www.fupress.com/bsfm-jems

Cuadrado-Esclapez, Georgina, et al. (2016). Bilingual dictionary of scientific and technical metaphors and metonymies. Engineering, architecture, physical activity, and sports sciences. Routledge.

Hartmann, Reinhard R. K. (2005). Pure or hybrid? The development of mixed dictionary genres. Linguistics and Literature 3(2), 193 - 208. http://facta.junis.ni.ac.rs/lal/lal2005/lal2005-06.pdf

Hasanah, Hasyim. (2017). Hermeneutik ontologis-dialektis Hans-Georg Gadamer. Jurnal At-Taqaddum. 9(1), $1-32$.

https://journal.walisongo.ac.id/index.php/attaqaddu $\mathrm{m} /$ article/view/1785/pdf

Iser, Wolfgang. (1974). The implied reader: patterns of communication in prose fiction from Bunyan to Beckett. The Johns Hopkins University Press

Jauss, Hans Robert. (1982). Toward an aesthetic of reception. Trans. Timothy Bahti. University of Minnesota Press.

Karpova, Olga. (2018). Shakespeare terminology with special reference to Shakespeare Arden dictionaries. Respectus Philologicus, 33(38), 9-16. https://www.journals.vu.lt/respectusphilologicus/article/view/13067/ 11887

Karpova,Olga. (2019). Modern English dictionaries: A foreign user's view. Respectus Philologicus, 36(41), 11-18. https://www.journals.vu.lt/ respectusphilologicus/article/view/14623/13590

Malekzadeh, Maryam. (2020). Genre analysis of abstract article sections across translation studies and English literature. Language Art, 5(1), 101-114. https://www.languageart.ir/index.php/LA/article/vie $\underline{w} / 128$

Oktavianti, Ikmi Nur. (2019). Necessity and obligation models in English academic discourse: A corpusbased analysis. Indonesian Journal of English 
Language Teaching and Applied Linguistics, 4(1), 47-59.

http://ijeltal.org/index.php/ijeltal/article/view/312/p df

Sari, Ratih N. (2016). Learning vocabulary through paper and online-based dictionary. Journal of ELT Research, $\quad 1(2), \quad 144-157$. https://journal.uhamka.ac.id/index.php/jer/article/vi ew/54/72

Siqueira, M., et al. (2009). Metaphor identification in a terminological dictionary. Ibérica, 17, 157-174. http://www.aelfe.org/documents/10_17_Siqueira.pd f

Vygotsky, L. S. (1930/2004). Imagination and creativity in childhood. Journal of Russian and East European Psychology, 42(1), 7-97. https://www.marxists.org/archive/vygotsky/works/1 927/imagination.pdf

Zemke, John. (2017). Units of measurement: Oral tradition, translation studies, and corpus linguistics. SEFAD, (37): 225-238. https://pdfs.semanticscholar.org/35a9/da0054efc2e3 f0bf084ff84198111fcd4d69.pdf? ga=2.191097577. $\underline{2141887280.1599383557-480929288.1599383557}$ 